\title{
Black Mn-Fe crusts as markers of abrupt palaeoenvironmental changes in El Soplao Cave (Cantabria, Spain)
}

\author{
Fernando Gázquez ${ }^{1}$, Jose Maria Calaforra ${ }^{1}$ and Paolo Forti ${ }^{2}$
}

\begin{abstract}
:
Fernando Gázquez F., Calaforra J. and Forti P. 2011. Black Mn-Fe crusts as palaeoenvironmental markers. International Journal of Speleology, 40 (2), 163-169. Tampa, FL (USA). ISSN 0392-6672. DOI 10.5038/1827-806X.40.2.8

Peculiar iron and manganese deposits coating walls, floors and ceilings of many galleries are one of the special features of the El Soplao Cave (Cantabria, Spain). These speleothems appear to have been deposited over wall clay deposits, as well as forming part of flowstones. Structure of crusts is essentially amorphous but several manganese and iron oxides were identified like goethite and birnessite, though all occur with a low degree of crystallinity. In the outer layer of the crusts, alteration iron minerals appear that derive from previous minerals in a process probably mediated by microorganisms. EDX microanalyses report fairly high values of Fe and $\mathrm{Mn}$ in the crusts, though the $\mathrm{Mn} / \mathrm{Fe}$ ratio varies considerably as a function of distance from the substrate/bedrock. The present study proposes a genetic model for crust speleothems in El Soplao, based on oscillations of the phreatic level. The origin of these deposits is related to mobilization, under phreatic conditions, of polymetallic sulfides in the host rock. Metal ions (including Fe ${ }^{2+}$ and $\mathrm{Mn}^{2+}$ ) released into the cave under reducing conditions, are oxidized and fixed in a process mediated by bacteria, giving rise to oxides and hydroxides of low crystallinity. The presence of various black intercalated layers in aragonite flowstones indicate periods when cave conditions suddenly changed from vadose, when aragonite is precipitated, to phreatic and epiphreatic conditions, when the $\mathrm{Mn}-\mathrm{Fe}$ deposits are precipitated. Subsequently, vadose conditions were re-established, leading to the final stages of precipitation of aragonite recorded in the flowstone and recent aragonite helictites on the surface of the Mn-Fe crusts.
\end{abstract}

Keywords: El Soplao Cave, manganese iron crust, speleothems

Received 31 December 2010; Revised 2 February 2011; Accepted 5 March 2011

\section{INTRODUCTION}

Polymetallic oxides and hydroxides are minerals frequently encountered in caves, and iron and manganese ones are especially abundant in subterranean environments (Hill \& Forti, 1997). Over the last fifty years, the mineralogy, morphology and genesis of this kind of speleothems has been studied in a variety of caves (Crabtree, 1962; Moore, 1981; Gascoine, 1982; Hill, 1982; Kashima, 1983; Peck, 1986; Jones, 1992; Onac, 1996; Onac et al., 1997; White et al., 2009). In some cases, research focussed on the role of microorganisms in the precipitation of these oxides (Peck, 1986; Boston et al., 2001; Spilder et al., 2005).

Manganese, soluble in its divalent form $\left(\mathrm{Mn}^{2+}\right)$ is oxidized to trivalent $\left(\mathrm{Mn}^{3+}\right)$ or tetravalent manganese $\left(\mathrm{Mn}^{4+}\right)$ in superficial environments at low temperature in a process that is generally mediated by microorganisms (Calvert \& Pedersen, 1996; Jürgensen et al., 2004).

\footnotetext{
${ }^{1}$ Water Resources \& Environmental Geology, University of Almeria, La Cañada de San Urbano s/n, 04120 Almeria, Spain (jmcalaforra@ual.es).
}

${ }^{2}$ Italian Institute of Speleology, University of Bologna, Via Zamboni 67, 40126 Bologna, Italy (paolo.forti@unibo.it).
Oxides of $\mathrm{Mn}^{3+}$ and $\mathrm{Mn}^{4+}$ have a complex mineralogy and a wide range of crystalline structures (Post, 1999). The mineralogy of some manganese oxide speleothems is not easy identifiable in many cases (Looney, 1969; White et al., 2009). In few cases, the manganese minerals have sufficient crystallinity to identify them (Onac et al., 1997; Boston et al., 2001; White et al., 2009). The main manganese minerals deposited in caves are birnessite, romanechite and todorokite (Hill and Forti, 1997), though rancieite and pyrolusite have also been identified (White et al., 2009). Also, the clay minerals are closely linked to the formation of $\mathrm{Mn}$ oxides and hydroxides, such as vernardite, ranciéite, birnessite and todorokite (Chukhrov et al., 1980).

Manganese oxides usually occur in caves as black crusts on walls and floors. Sometimes they form the base of speleothems, but they rarely form part of stalactites, stalagmites or flowstones (Hill \& Forti, 1997). "Fossilized" layers of $\mathrm{Fe}$ and $\mathrm{Mn}$ oxides into other speleothems have only been described in a few studies (Peck, 1986; Provencio \& Polyak, 2001).

This paper analyzes the chemistry and mineralogy of the manganese crusts on the ceilings and walls of the El Soplao Cave and their relation with other deposits of the cave. Mineralogical and geochemical data are presented; these enabled a model of the genesis of these peculiar speleothems to be constructed, related 
to extreme changes in water level in the cave. Some of these pavement deposits has been recently analyzed (Rossi et al., 2010) with a "stromatolitic" interpretation for their genesis but no palaeoclimatic interpretation have been provided.

\section{GEOLOGICAL SETTING}

El Soplao Cave $\left(43^{\circ} 17^{\circ} 45,42^{\prime \prime N}-4^{\circ} 26^{\prime} 45\right.$, $76^{\prime \prime W) ~ l i e s ~ i n ~ t h e ~ S i e r r a ~ d e ~ A r n e r o, ~ i n ~ t h e ~ E s c u d o ~}$ de Cabuérniga mountain range (Cantabria, North Spain). The Sierra de Arnero is a chain of mountains running parallel to the Cantabrian Coast, between the Bustriguado and Nansa valleys (municipal districts of Valdáliga, Rionansa and Herrerías) (Fig. 1).

The cave entrance is at $540 \mathrm{~m}$ a.s.1 and it extends over $20 \mathrm{~km}$ length, with difference in level of barely 50 metres. The cave runs mainly NW-SE, with a secondary axis NE-SW. El Soplao has been open as a show cave since 2005. An artificial mine mouth (Isidra Gallery) serves as an entrance for touristic visits. There are also two natural cave entrances: Torca Ancha and Torca Juñosa, but access to the cave is difficult. Preliminary studies inside and outside the cave suggest other entrances to the cave may exist, which influence the microclimate dynamics and cave environment.

El Soplao Cave is excavated in Aptian rocks formed in a shallow continental platform of marine carbonates (Florida Unit). Permo-Triassic bed consists of siliciclastic conglomerate and shale. This region contains considerable metallogenic interest because of the large patches of dolomitization that have occurred in the carbonates (López-Cilla et al., 2009). Important deposits of lead and zinc sulfides (galena and spharelite) occur in the Florida mine and in the Soplao Cave itself (García-Mondéjar et al., 1996; Quesada et al., 2005). These ore minerals contain up to $320 \mathrm{ppm}$ of Mn (Velasco et al., 2003).
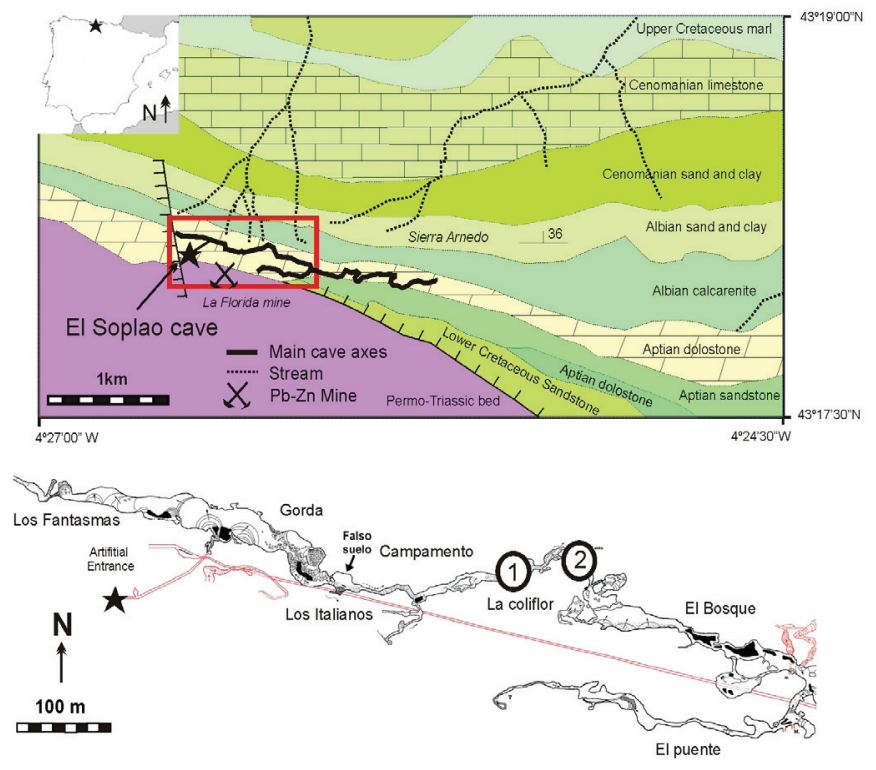

Fig. 1. Location and geological setting of El Soplao Cave, and a plan view of a cave part. Situation of sampling points: 1, Campamento Gallery, manganese crusts on the walls and ceiling (SPL-MNC, SPL-ARA, SPL-PRO) and on the floor (SPL-FLO), 2, Pasillo de los Cubos, aragonite flowstone with layers of manganese oxide and detrital deposits (SPL-FLW-07). Cartography modified from IGME (1976); cave topography courtesy of El Soplao S.L.

\section{DESCRIPTION OF THE SAMPLES}

Samples of the black crusts were collected from the ceiling of Campamento Gallery (SPL-MNC-01). The crusts consist of 0.01 to $3 \mathrm{~cm}$ thick lamina that coat earlier clay detrital deposits on the walls and ceiling of the gallery. These crusts form a continuous layer over the gallery walls, though the crust has been dislodged in places, exposing the underlying detrital material. The crusts are consolidated and their surfaces are smooth (Fig. 2A), though there are some superficial marks related to capillarity flows over the surface (Fig. 3A). The convex surfaces of the cave roof often display abundant aragonite and/or calcite helictites and anthodites. These aragonite speleothems (SPLAAR-05) are also analysed in this paper (Fig. 2B).

Ferromanganese oxides also cover the floors of the galleries. They have a marked biogenic character and display soft consistency. These sediments have also been studied by Rossi et al. (2010) and consist of sand and gravel intercalated between Mn oxide-rich layers. They were sampled (SPL-FLO-06) in order to compare them to other Fe and $\mathrm{Mn}$ deposits in the cave (Fig. 3B). On occasions, these deposits form the base of other calcite and aragonite speleothems (Fig. 2C).

Thirty metres away from Campamento Gallery a small passageway known as Pasillo de los Cubos can be reached (Fig. 1). This part of the cave exhibits a flowstone of intercalated aragonite and cemented detrital material (SPL-FLW-07). The final phases in the formation of this speleothem incorporated dark layers about $0.5 \mathrm{~mm}$ thick, which have been "fossilized" by a $5 \mathrm{~mm}$-thick aragonite layer (Gázquez et al., 2010) (Fig. 2D). Detrital materials also appear covering aragonite and calcite stalactites in the Campamento Gallery (Fig. 2E).

\section{METHODOLOGY}

SEM microphotographs were taken using a HITACHI S-3500 instrument in high vacuum mode. The samples were previously dried and metalized with a $15 \mathrm{~nm}$ coating of Au. EDX microanalyses (energy dispersive $\mathrm{x}$-ray spectroscopy) used the same instrument coupled to an Oxford INCA 7210 X-ray detector, using a voltage of $20 \mathrm{kV}$. The diameter of the beam was approximately $1 \mu \mathrm{m}$. The limit of detection of this technique enables major elements like Fe, Mn, $\mathrm{O}, \mathrm{Si}, \mathrm{Ca}$ and $\mathrm{C}$ to be analysed (Table 1). The detrital substrate in contact with the inner part of the crust was analyzed (SPL-MNC-01a and SPL-MNC-01b). Several microanalyses were performed, both in the external surface of the crusts (SPL-MNC-02a and SPL-MNC-02b) and the surface in contact with the underlying clay (SPL-MNC-03a, SPL-MNC-03b, SPLMNC-03c and SPL-MNC-03d). Alteration minerals on the external crust surface (SPL-MNC-04a and SPLMNC-04b) and six points through a section of the crust (SPL-PRO, 01 to 06) were also analysed. Floor $\mathrm{Mn}-\mathrm{Fe}$ sediments were investigated by means of EDX (SPL-FLO-06c, SPL-FLO-06d, SPL-FLO-06e and SPLFLO-06f). Finally, a Mn-Fe layer of the Pasillo de los Cubos flowstone was analyzed (SPL-FLW-07).

Mineral analysis using X-ray diffraction (XRD) was done at ambient temperature in a single-crystal diffractometer using a BRUKER APEX CCD area detector, modified for analysis of powdered samples. 

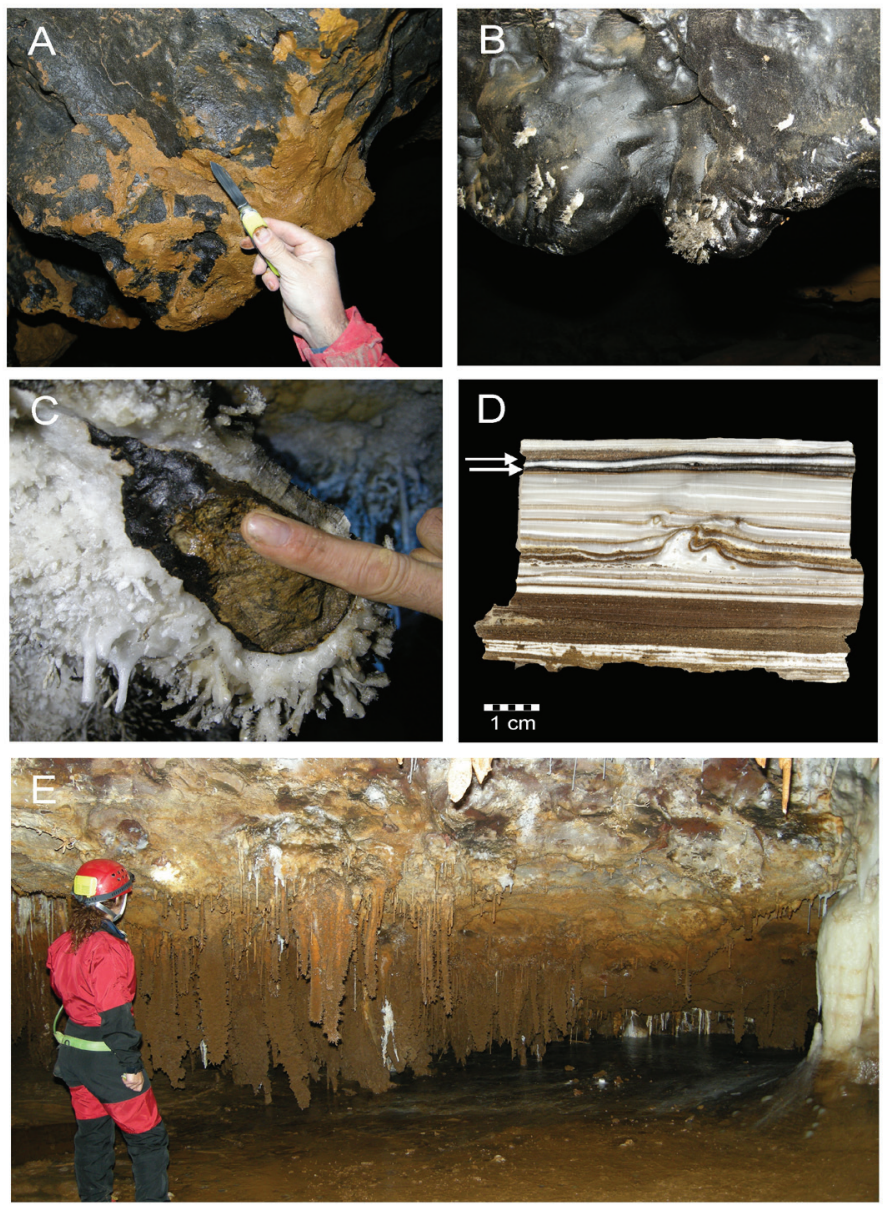

Fig. 2. A. Crusts of Mn-Fe overlying clay deposit on the ceiling of the Campamento Gallery. B. Helictites on the ferromanganese crusts in the Campamento Gallery indicate that the crusts cannot be relatively recent formations. C. Deposits of $\mathrm{Mn}-\mathrm{Fe}$ oxides covered by aragonite helictites on the wall of Campamento Gallery. D. Aragonite flowstone with intercalations of cemented detrital material derived from flood events in the Pasillo de los Cubos. The arrows point two dark layers of Mn-Fe oxides (SPL-FLW-07). E. Campamento Gallery. Aragonite stalactites coated in clay indicate flood events.

$\mathrm{Mo}_{\mathrm{K \alpha}}$ cathode radiation was used $(\lambda=0.71073 \AA$ ) using the $\omega$ scanning method, within angular limits $1.96<$ $\theta<23.298$. This technique allows minimal quantities of samples to be analysed (<0.05 mg) but carries the disadvantage of low resolution in the resulting diffractograms. Both samples from ceiling (SPLMNC-02) and from floor (SPL-FLO-06) were analyzed.

Quantitative chemical analysis of samples was done using X-ray fluorescence (wavelength dispersive XRF) with a BRUKER S4 Pioneer instrument. Total samples of sediments taken from the cave floor were analysed (SPL-MNC-06a and SPL-MNC-06b), along with aragonite needles that had developed over the crusts (SPL-AAR-05). All analyses were performed at the Technical Services Area of the University of Almeria (Spain).

\section{RESULTS}

Mineralogical analysis of the crusts by XRD detected various mineral phases of ferromanganese oxides, including goethite and birnessite, though all the crusts had a low crystallinity and were poorly defined in the diffractogram. Dolomite and quartz were detected on the surface of the crusts using XRD and Fe oxide-hydroxides were also found and analysed using EDX (Table 1). The mineralogy of the floor deposits from Campamento Gallery is very similar to the ceiling crusts, with $\mathrm{Mn}-\mathrm{Fe}$ oxides and some unidentified clay phases. Eventually, aluminium oxyhydroxides also appear in some floor crusts samples detected by EDX (Fig. 3C and SPL-FLO-06f in Table 1).

The major elements in the crusts from El Soplao are $\mathrm{Mn}$ and $\mathrm{Fe}$, though the $\mathrm{Mn} / \mathrm{Fe}$ ratio varies considerably depending on its distance from the host rock (Fig. 4). The chemical composition of the ferromanganese crusts varies according to the zone in which the microanalysis is done. The inner part of the crust, in contact with the detrital substrate (Fig. 3D), contains high concentrations of $\mathrm{Si}$ (50.2 wt\%.) and $\mathrm{O}$ (33.16 wt\%), and this corroborates with the presence of quartz grains as detected by XRD. The outer crust surface contains alteration minerals with high $\mathrm{Fe}$ content (26.24 wt\%), dolomite and detrital quartz. Microorganisms were detected on the rough surface of the crusts in Campamento Gallery (Fig. 3F).

Sr concentration is very low in the ferromanganese crusts $(0.0082 \mathrm{wt} \%$ ) (SPL-FLO-06a) compared to the analyzed aragonite helictites (0.6 wt\%) (SPLAAR-05). $\mathrm{Zn}$ appears in the majority of analyses in small quantities in the wall-ceiling crust $(<7 \mathrm{wt} \%)$, but its concentration is higher in the sediment sample taken from the cave floor (up to $23 \mathrm{wt} \%$ ). Moreover, Co (0.133 wt $\%)$, Ti (0.8160 wt\%), $\mathrm{Pb}(0.92 \mathrm{wt} \%)$ and
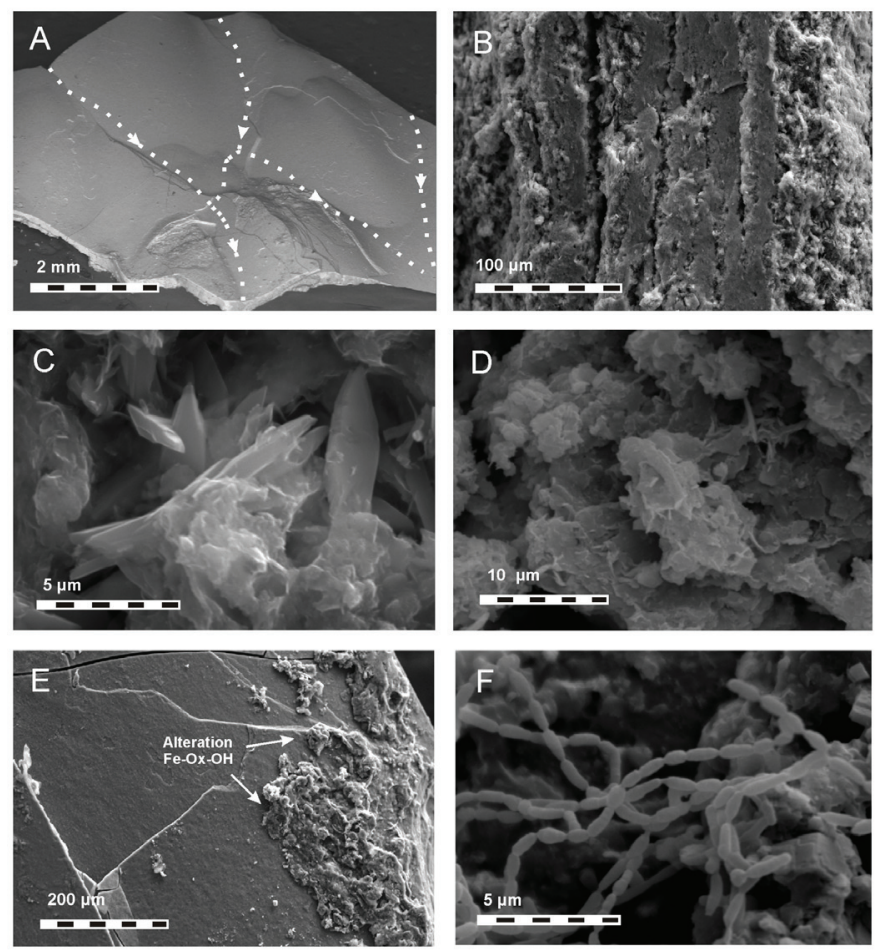

Fig. 3. Secondary electron images. A. Ferromanganese crust from the ceiling of Campamento Gallery. The white lines indicate the marks left by the condensation water flow B. Stratification of a biogenic sediment composed on Mn-Fe oxides, which formed on the floor of Campamento Gallery C. Aluminium oxides and hydroxides in the interior of the floor crusts. D. Clay substrate in Campamento Gallery, over which the crusts were precipitated. E. Alteration minerals (oxides-hydroxides of $\mathrm{Fe}$ ) on the surface of a crust from Campamento Gallery. F. Bacteria on the surface of a ferromanganese crust taken from Campamento Gallery. 
Table 1. Analyses of major elements. Analytical error ranges from $\pm 0.33 w t \%$ for oxygen to $\pm 0.13 w t \%$ for aluminium. Error in Fe and $\mathrm{Mn}$ measurements was $\pm 0.2 \mathrm{wt} \%$.

\begin{tabular}{|c|c|c|c|c|c|c|c|c|c|c|c|}
\hline Samples & $\mathrm{O}(w t \%)$ & $\begin{array}{c}\mathrm{Fe} \\
(w t \%)\end{array}$ & $\begin{array}{c}\text { Mn } \\
(w t \%)\end{array}$ & $\begin{array}{c}\mathbf{S i} \\
(\mathbf{w t} \%)\end{array}$ & $\begin{array}{c}\mathrm{C} \\
(w t \%)\end{array}$ & $\begin{array}{c}\mathrm{Al} \\
\text { (wt\%) }\end{array}$ & $\begin{array}{c}\mathrm{Mg} \\
(\mathrm{wt} \%)\end{array}$ & $\begin{array}{c}\mathrm{Ca} \\
(\mathbf{w t} \%)\end{array}$ & $\begin{array}{c}\mathrm{Zn} \\
(\mathbf{w t} \%)\end{array}$ & $\mathrm{Mn} / \mathrm{Fe}$ & Sample description \\
\hline SPL-MNC-01a & 33.16 & 3.08 & 1.16 & 50.24 & 12.35 & n.d & n.d & n.d & n.d & 0.38 & detrital substrate $\left(\mathrm{SiO}_{2}\right)$ \\
\hline SPL-MNC-01b & 44.9 & 13.23 & 17.54 & 9.72 & n.a & 6.82 & 1.15 & 1.72 & n.d & 1.33 & detrital substrate (clay) \\
\hline SPL-MNC-02a & 31.3 & 28.52 & 13.72 & 9.82 & 8 & 4.96 & 1.51 & 1.64 & n.d & 0.48 & superficial crust \\
\hline SPL-MNC-02b & 26.84 & 21.65 & 33.35 & 5.68 & 2.97 & 2.87 & 1 & 2.83 & 1.59 & 1.54 & superficial crust \\
\hline SPL-MNC-03a & 39.14 & 8.03 & 29.35 & 6.49 & 6.24 & 4.06 & 1.79 & 2.07 & 2.29 & 3.66 & internal crust \\
\hline SPL-MNC-03b & 46.46 & 7.73 & 21.18 & 9.95 & n.a & 6.23 & 1.15 & 1.88 & 3.74 & 2.74 & internal crust \\
\hline SPL-MNC-03c & 11.72 & 15.06 & 55.59 & 4.18 & 5.68 & 1.48 & 0.54 & 3.21 & 0.82 & 3.69 & internal crust \\
\hline SPL-MNC-03d & 31.11 & 10.18 & 40.82 & 3.01 & n.a & 2.43 & 0.83 & 3.62 & 6.18 & 4.01 & internal crust \\
\hline SPL-MNC-04a & 48.67 & 12.34 & 1.41 & 19.96 & n.a & 11.68 & 0.99 & 0.33 & 1.19 & 0.11 & Alteration Fe minerals \\
\hline SPL-MNC-04b & 44.03 & 26.24 & 0.96 & 5.84 & 9.33 & 5.08 & 3.42 & 4.6 & n.d & 0.04 & Alteration Fe minerals \\
\hline SPL-AAR-05F & n.a & 0.1 & 0.006 & 5.9 & n.a & n.a & 1 & n.a & n.d & 0.06 & aragonite helictite \\
\hline SPL-FLO-06a ${ }^{F}$ & 30.51 & 13.36 & 14.73 & 7.17 & n.a & 10.09 & 0.61 & 2.1 & 4.814 & 1.10 & Floor deposit \\
\hline SPL-FLO-06b & 29.73 & 10.53 & 17.52 & 6.253 & n.a & 11.25 & 0.256 & 1.972 & 4.122 & 1.66 & Floor deposit \\
\hline SPL-FLO-06c & 39.89 & 5.09 & 25.77 & 3.79 & n.a & 6.37 & 0.74 & 1.58 & 16.37 & 5.06 & Floor deposit \\
\hline SPL-FLO-06d & 30.81 & 4.93 & 28.53 & 3.9 & n.a & 6.5 & 0.69 & 1.42 & 23.22 & 5.79 & Floor deposit \\
\hline SPL-FLO-06e & 27.62 & 6.97 & 23.34 & 5.46 & n.a & 10.76 & 1.3 & 0.42 & 23.51 & 3.35 & Floor deposit \\
\hline SPL-FLO-06f & 61.39 & 1.25 & 3.25 & 2.18 & n.a & 27.72 & n.d & 0.19 & 3.78 & 2.60 & Floor deposit \\
\hline SPL-PRO-01 & 15.91 & 9.73 & 35.11 & 0.94 & 34.11 & n.d & n.d & 0.33 & 1.98 & 3.61 & Crust profile (1) \\
\hline SPL-PRO-02 & 4.63 & 22.99 & 61.88 & n.d & 6.8 & n.d & n.d & 0.92 & 2.78 & 2.69 & Crust profile (2) \\
\hline SPL-PRO-03 & 14.2 & 12.39 & 42.78 & 0.79 & 27.2 & 0.4 & n.d & 0.48 & 1.76 & 3.45 & Crust profile (3) \\
\hline SPL-PRO-04 & 37.55 & 8.16 & 21.33 & 1.62 & 28.7 & 1.18 & 0.55 & 0.92 & n.d & 2.61 & Crust profile (4) \\
\hline SPL-PRO-05 & 8.42 & 27.96 & 37.08 & 0.6 & 22.38 & n.d & n.d & 0.54 & 2.22 & 1.33 & Crust profile (5) \\
\hline SPL-PRO-06 & 39.64 & 26.58 & 20.33 & 4.48 & n.d & 3.48 & 1.13 & 1.88 & 2.19 & 0.76 & $\begin{array}{c}\text { Crust profile (6) } \\
\text { Mn crust in aragonite }\end{array}$ \\
\hline SPL-FLW-07 & 45.97 & 4.83 & 11.9 & 6.93 & n.a & 3.94 & 1.47 & 10.45 & 14.62 & 2.46 & flowstone \\
\hline
\end{tabular}

n.a. = not analyzed n.d. = not detected $\mathrm{F}=$ analyzed by XRF (Sr, Ti, Co, and Pb concentration are reported in the main text).

other transition elements (all $<0.1 \mathrm{wt} \%$ ) were detected by XRF (SPL-FLO-06a and SPL-FLO-6b) in the floor crusts.

Aragonite needles (SPL-AAR-05), taken from the surface of the manganese crusts on the ceiling of Campamento Gallery, were low in Fe (0.1 wt\%) and $\mathrm{Mn}$ $(0.006 \mathrm{wt} \%)$. However, their silica content is significant (5.9 wt\%); they have a similar Mg concentration to the crusts (1 wt\%) and are enriched in $\mathrm{Sr}(0.6 \mathrm{wt} \%)$.

Data from other analysed speleothems (e.g., aragonite stalagmites) in El Soplao Cave showed negligible concentrations of $\mathrm{Si}$. In contrast, $\mathrm{Sr}$ concentration was greater (approx. $0.4 \mathrm{wt} \%$ ) than that obtained in the crusts, but similar to the aragonite helictites (0.6 wt\%). These speleothems had concentrations of $\mathrm{Mg}(0.06 \mathrm{wt} \%), \mathrm{Fe}(0.001 \mathrm{wt} \%)$ and $\mathrm{Mn}(0.0001 \mathrm{wt} \%)$, which were very far from the content in the Fe and Mn crusts.

$\mathrm{Zn}$ concentration in the black crusts that form part of the aragonite flowstone in the Pasillo de los Cubos (SPL-FLW-07) is considerably higher than in the Mn crusts on the ceiling of the cave, but similar to the floor deposits. Concentration of $\mathrm{Mn}$ and Fe are less than in the floor deposits analyzed and similar to the concentrations found in the ceiling crusts. In general it has been found that floor crust are enriched in $\mathrm{Zn}$ and depleted in $\mathrm{Fe}$ and $\mathrm{Mn}$ compared to the wall-ceiling crust.

\section{DISCUSSION}

Precipitation of iron or manganese oxides in caves depends to a certain extent on the $\mathrm{pH}$ of the medium. At around $\mathrm{pH} 6$, precipitation of iron oxides is frequent, whilst close to $\mathrm{pH} 8.5$ manganese oxides can be precipitated (Onac, 1996). Small changes in $\mathrm{pH}$ can cause precipitation of these oxides. At neutral $\mathrm{pH}$, $\mathrm{Fe}$ and Mn oxides are precipitated simultaneously.

Fig. 4 shows the $\mathrm{Mn} / \mathrm{Fe}$ ratio over the growth sequence of a ferromanganese crust (600 $\mu \mathrm{m}$ thick) deposited on the ceiling of Campamento Gallery. The $\mathrm{Mn} / \mathrm{Fe}$ ratio diminishes with distance from the substrate rock. This fact indicates that iron oxides predominate in the outer crust, while Mn oxides are more abundant in the inner part. Since the Mn/Fe ratio depends on the $\mathrm{pH}$ of the medium in which it was precipitated, it is clear that close to the carbonate host rock, high alkalinity medium, Mn oxides are precipitated, while the lower $\mathrm{pH}$ in the later stages of formation, led to greater precipitation of Fe oxides.

There are two possible sources of $\mathrm{Mn}$ and $\mathrm{Fe}$ in $\mathrm{E} 1$ Soplao Cave. The origin of $\mathrm{Mn}-\mathrm{Fe}$ that gave rise to formation of the crusts in El Soplao could be linked to mobilization of these metals from polymetallic sulfide mineralizations in the host rock. The phreatic conditions, when the cave was submerged under aquifer water, led to mobilization of these elements. Such a process is only possible in an anoxic medium, 


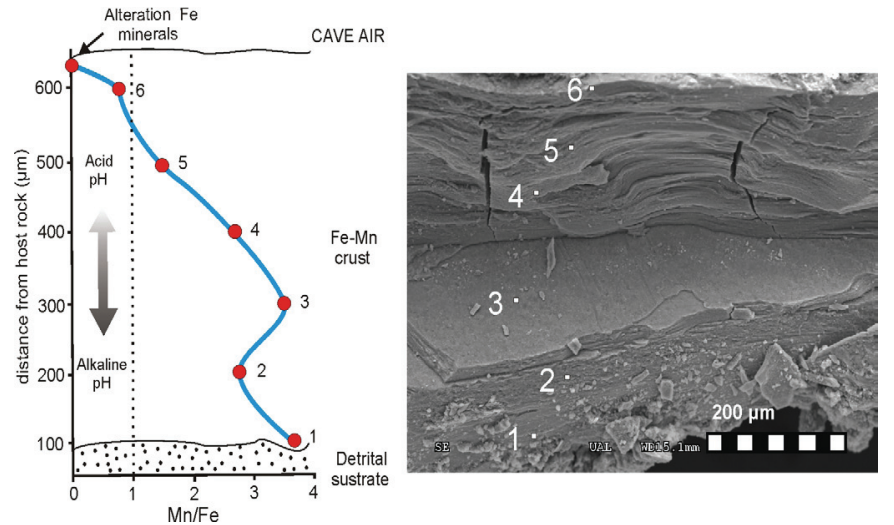

Fig. 4. Mn/Fe ratio (wt\%) through the stratigraphic sequence of a ferromanganese crust in Campamento Gallery. The Fe/Mn ratio is higher close to the substrate and diminishes towards the exterior. The $\mathrm{Mn} / \mathrm{Fe}$ ratio is related to the preferential precipitation of oxides of $\mathrm{Fe}$ or of $\mathrm{Mn}$, as determined by the $\mathrm{pH}$ of the medium (see text).

when $\mathrm{Mn}$ is in its reduced state $\left(\mathrm{Mn}^{2+}\right)$ (Calvert \& Pedersen, 1996; Jürgensen et al., 2004). On the other hand, dissolution of dolostone host rock (Fig. 5A), rich in $\mathrm{Mn}-\mathrm{Fe}(0.2$ and $1.5 \mathrm{wt} \%$ respectively, Bustillo et al., 1992) under anoxic conditions, is a significant source of $\mathrm{Mn}$ and $\mathrm{Fe}$ that is released into the aquifer water.

During other periods, the cave was partly submerged. Due to massive inflow of water into the cave, the flow regime became turbulent (Fig. 5B) and carried large amounts of detritus in suspension. This material was later deposited in different parts of the cave. Evidences of these flood events inside E1 Soplao Cave are documented by following observations: while aragonite stalactites in some parts of the cave are white, those in Campamento Gallery are covered in clay and detrital deposits (Fig. 2E). Further evidence of old torrential flows is seen in the aragonite flowstone in the Pasillo de los Cubos, where detrital material has been trapped and fossilized between aragonite layers (Gázquez et al., 2010) (Fig. 2D).

Suspended solids were deposited on the cave walls, ceilings and speleothems when the flow energy decreased (Fig. 5C). During this phase, clays were adhered to the cave surfaces and decanted, serving as substrate for the formation of the Mn-Fe crust in Campamento Gallery and in the flowstone in Pasillo de los Cubos (Fig. 2D). The relatively high concentration of $\mathrm{Mn}$ (17.54 wt\%) and Fe (13.23 wt\%) in the clay substrate on which the crusts deposited conform our above scenario.

In our model we propose that, unlike the crust of Pasillo de los Cubos, in Campamento Gallery Mn and $\mathrm{Fe}$ are exuded from the clay and gives rise to ceiling and wall crusts in El Soplao. Under epiphreatic aerobic conditions, metals are oxidised on the surface of the clay, in a process that could be mediated by microorganisms (Fig. 5D) and ionic exchange at the water-clay interface. In the case of the crusts on the walls and ceiling of Campamento Gallery, condensation may have played a fundamental role in the oxidation of Mn and Fe. The surface of these crusts shows irregularities, which document the vertical downward water flow that favoured the oxidation and subsequent precipitation of $\mathrm{Mn}-\mathrm{Fe}$ oxides.
Microbial involvement in the precipitation of MnFe oxides and hydroxides seems clear, and has been already documented from other caves (Spilder et al., 2005). Microorganisms activity have been found within the Mn-Fe deposits in El Soplao (Rossi et al., 2010) and fresh microorganisms have been detected on the rough surface of the crusts in Campamento Gallery (Fig. 3F). Judging by their morphology, they are probably streptobacilli or actinomycetes. Their activity not only seem to be related to initial Mn-Fe crusts (Fig. 5D) but also must have to do with the alteration Fe minerals and maybe the dolomite that appear over the crusts (Fig. 5E).

On the other hand, dolomite in caves is frequently associated with other minerals such as calcite, aragonite, huntite and hydromagnesite. Recent studies have demonstrated that microbial activity can play a fundamental role in the precipitation of this mineral (Jones, 2010). Most research supports the idea that dolomite forms part of the cave speleothems through alteration of pre-existing minerals (Hill \& Forti, 1997; Alonso-Zarza \& Martín-Pérez, 2008). In the case of El Soplao Cave, dolomite could be related
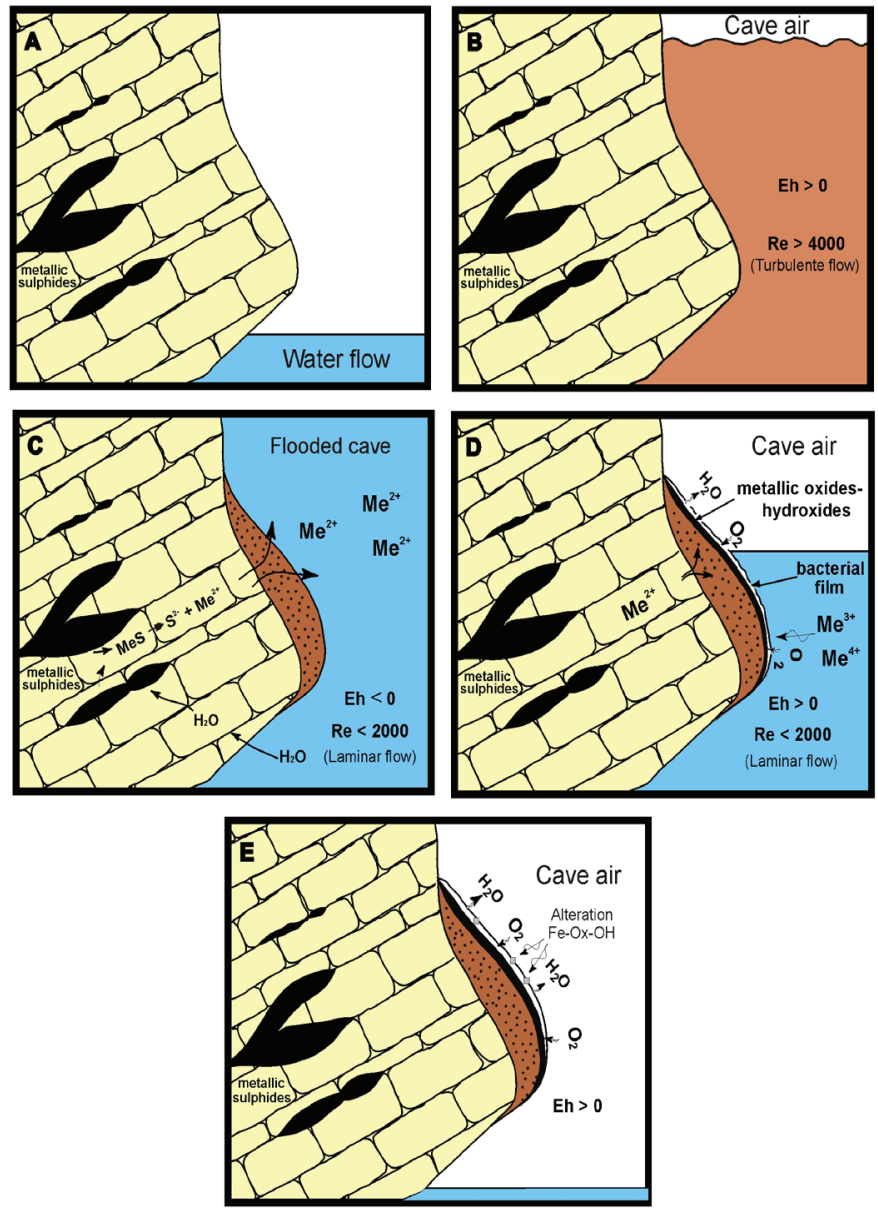

Fig. 5. Genesis of the Mn-Fe crusts in El Soplao Cave. A. The host rock contains metallic sulfide minerals B. Cave flood events generated turbulent flow (i.e., $\operatorname{Re}>4000$ ) enhancing the transport of detrital material. C. Sedimentation of detrital material and mobilization of reduced ions $\left(\mathrm{Mn}^{2+}\right.$ and $\left.\mathrm{Fe}^{2+}\right)$ in a less turbulent flow (i.e., $\mathrm{Re}<2000$ ) D. Oxidation of metallic ions leads to the formation of $\mathrm{Mn}-\mathrm{Fe}$ crusts in an epiphreatic environment. E. Alteration of $\mathrm{Mn}-\mathrm{Fe}$ crusts in an aerobic environment and precipitation of Fe oxides-hydroxides (Note: Reynolds number is only an estimate for referring to the energy of the medium). 

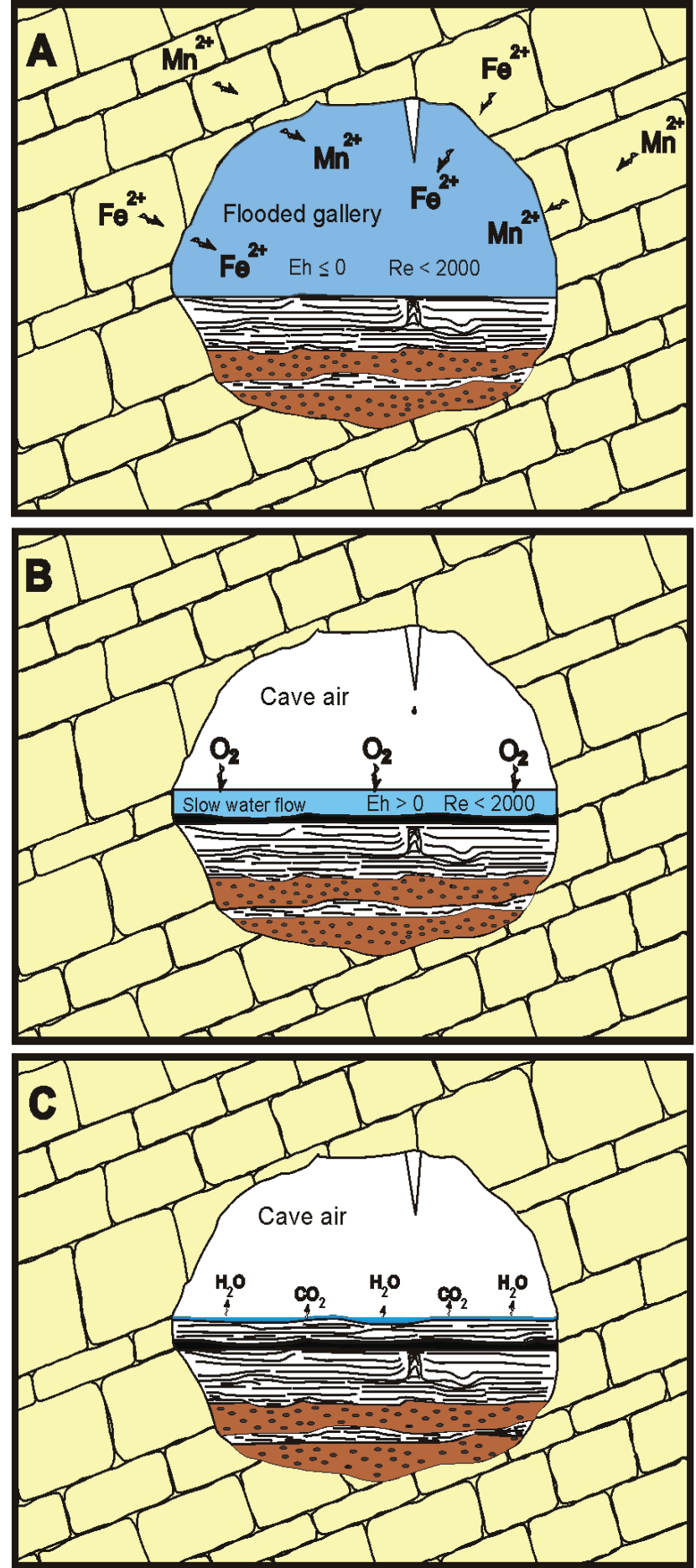

Black crusts $\Rightarrow$ Aragonite layers (Mn-Fe-Ox)

Detrital cemented layers

Fig. 6. Genesis of Mn-Fe oxide layers in the aragonite flowstone in the Pasillo de los Cubos A. Phreatic period. The Pasillo de los Cubos is submerged bellow aquifer water-level. Mobilization of metals derived from mineralized host rock occurs under anoxic conditions (Eh $\leq 0)$ and laminar flow (i.e., $\operatorname{Re}<2000)$ B. Epiphreatic period. Precipitation of $\mathrm{Mn}-\mathrm{Fe}$ oxides and hydroxides due to a fall in the phreatic level that allowed the diffusion of oxygen in the sheet of water, causing oxidation of $\mathrm{Fe}$ and $\mathrm{Mn}(\mathrm{Eh}>0)$ under a laminar regime (i.e., $\mathrm{Re}<2000) \mathrm{C}$. Vadose period. Precipitation of aragonite from laminar water flow under vadose conditions due to water degassing (Note: Reynolds number is only an estimate for referring to the energy of the medium). to microbial activity and Fe-Mn crusts deposits. However, the origin of dolomite could also be linked to the dolostone host rock.

A general scheme of the precipitation sequence of El Soplao Cave flowstones could be as follows: (1) the anoxic-phreatic events favoured the enrichment of $\mathrm{Mn}-\mathrm{Fe}$ ions in the water (Fig. 6A), (2) epiphreatic oxygenate conditions allowed $\mathrm{Mn}-\mathrm{Fe}$ precipitation by metal oxidation of the black crusts over clay material (Fig. 6B) and finally (3) the precipitation of aragonite by water degassing (Fig. 6C). This situation also alternated with phreatic periods when detrital material was sedimented by floods occurred, especially in the early stages of the flowstone genesis (Fig. 2D). This final stage of aragonite precipitation is also reflected in the crusts in Campamento Gallery and over the biogenic sediments on the floor at various points of the cave (Fig. 2B and 2C).

\section{CONCLUSIONS}

Ferromanganese crusts in El Soplao Cave appear on the floor, walls and ceiling of certain galleries. On the cave floors, they take the form of biogenic sediments, and even appear inter-layered in aragonite flowstones. The crusts seem to have originated as a result of the alternation between phreatic and vadose periods. Mobilization of $\mathrm{Mn}^{2+}$ and $\mathrm{Fe}^{2+}$ from polymetallic sulfides occurred under anoxic conditions when the cave was submerged. Clays deposited on the surfaces of the galleries served as the substrate onto which the Fe-Mn crusts were precipitated. Under epiphreatic conditions, oxidation of $\mathrm{Mn}$ and $\mathrm{Fe}$ under aerobic conditions mediated by bacteria occurred. Finally recent bacteria activity favoured the precipitation of post-depositional minerals such as alteration $\mathrm{Fe}$ oxides and maybe dolomite.

Because the crusts also appear as intercalations between layers of aragonite in the flowstone speleothem indicate that vadose conditions (when aragonite was precipitated) alternated with phreatic and epiphreatic conditions (when Mn-Fe oxides and hydroxides were precipitated). Precipitation of aragonite could be associated with relatively dry periods inside the cave. In E1 Soplao Cave, these dry periods alternated with flooding phases that are unequivocally linked to pluviometric peaks in this region. Indirectly, the study of these special speleothems could help to date phreatic level changes in El Soplao Cave maybe linked to palaeoclimatic changes.

\section{ACKNOWLEDGEMENTS}

The authors are grateful for the support from the Servicios Centrales de Investigation of the University of Almeria, where the SEM photographs, EDX microanalysis, XRD mineralogy and XRF chemical analyses were done. We are especially grateful to the technicians, Esmeralda Urea and Sonia Mañas, responsible for these instruments. We should also like to thank the management of El Soplao S.L. for allowing us to use their facilities and access to the cave. This study has been financed through the "Paleogyp" project, CGL2006-01707/BTE and the research grant AP-2007-02799 from the Ministry of Science and Innovation of Spain. We thank Aleksandar Pačevski, Bogdan P. Onac and an anonymous reviewer for helpful suggestions. 


\section{REFERENCES}

Alonso-Zarza A. \& Martín-Pérez A., 2008 - Dolomite in caves: Recent dolomite formation in oxic, nonsulfate environments. Castañar Cave, Spain, Sedimentary Geology, 205 (3-4): 160-164.

Boston P.J, Spilde M.N., Northup D.E. Melim L.A., Sorok D.S., Kleina L.G., Lavoie K.H., Hose L.D., Mallory L.M., Dahm C.N., Crossey L. J. \& Schelble R.T., 2001 - Cave Biosignature Suites: Microbes, Minerals, and Mars. Astrobiology, 1 (1): 25- 54.

Bustillo M., Fort R., \& Ordóñez S., 1992 - Genetic implications of trace-element distributions in carbonate and non-carbonate phases of limestones and dolostones from western Cantabria, Spain. Chemical Geology, 97: 273-283.

Calvert S.E. \& Pedersen T.F., 1996 - Sedimentary geochemistry of manganese; implications for the environment of formation of manganiferous black shales. Economic Geology, 91 (1): 36-47.

Chukhrov F.V., Gorshkov A.I., Rudnitskaya E.S., Beresovskaya V.V. \& Sivtsov A.V., 1980 Manganese minerals in clays: a review. Clay and Clay minerals, 28 (5): 346-354.

Crabtree P.W., 1962 - Bog ore from Black Reef Cave. Cave Science, 4 (32): 360-361.

García-Mondéjar J., Agirrezabala L.M., Aranburu A., Fernández-Mendiola P.A., Gómez-Pérez I., LópezHorgue M. \& Rosales I., 1996 - The Aptian-Albain tectonic pattern of the Basque-Cantabrian basin (Northern Spain). Geological Journal, 31: 13-45.

Gázquez F., Delgado-Huertas A., Forti P., Stöll H. \& Calaforra J.M., 2010 - Variabilidad paleoambiental en la Cueva de El Soplao (Cantabria) a partir de la diversidad mineralógica de sus espeleotemas. In: J.J. Durán and F.Carrasco (Eds.). Cuevas: Patrimonio, Naturaleza, Cultura y turismo. Madrid. Asociación de Cuevas turísticas, 293-304 p.

Gascoine W., 1982 - The formation of black deposits in some caves of south east Wales. Cave Science, 9 (3): 167-175.

Hill C.A., 1982 - Origin of black deposits in caves. National Speleological Society Bulletin, 44: 15-19.

Hill C.A. \& Forti P., 1997 - Cave minerals of the World. National Speleological Society, Huntsville.

IGME 1976 - Mapa geológico de España E 1: 50000. Hoja 57. Cabezón de la Sal

Jones B. 1992 - Manganese precipitates in the karst terrain of Grand Cayman, British West Indies. Canadian Journal of Earth Science, 29 (6): 11251139.

Jones B. 2010 - The preferential association of dolomite with microbes in stalactites from Cayman Brac, British West Indies. Sedimentary Geology, 226 (14): 94-109.

Jürgensen A., Widmeyer J.R., Gordon R.A., BendellYoung L.I., Moore M.M. \& Crozier E.D., 2004 - The structure of the manganese oxide on the sheath of the bacterium Leptothrix discophora: An XAFS study. Amerian Mineralogist, 89: 1110-1118.
Khashima N., 1983 - On the Wad-minerals from the cavern environment. International Journal of Speleology, 13: 67-72.

Looney J., 1969 - Duncan Field Cave System Oklahoma's amazing maze. Natl. Speleolo. Soc. News, 27 (7): 95-98.

López-Cilla I., Rosales I., Najarro M., Martín-Chivelet J., Velasco F. \& Tornos F., 2009 - Etapas de formación de dolomías masivas del entorno de La Florida-El Soplao, Cantabria. Geogaceta, 47: 65-68.

Moore G.W., 1981 - Origin of black deposits in caves. Proceedings $8^{\text {th }}$ International Congress of Speleology, Bowling Green I \& II: 642-644 p.

Onac B.P., 1996 - Mineralogy of speleothems from caves in the Padurea Craiului Mountains (Romania), and their palaeoclimatic significance. Cave and Karst Science, 23 (3): 109-124.

Onac B.P., Pedersen R.B. \& Tysseland M., 1997 - Presence of rare-earth elements in black ferromanganese coating from Vântuliu cave (Romania). Journal of Cave and Karst Studies, 59 (3): 128-131.

Peck S.B., 1986 - Bacterial deposition of iron and manganese oxides in North American caves. National Speleological Society Bulletin, 48 (1): 26-30.

Post J.E., 1999 - Manganese oxide minerals: Crystal structures and economic and environmental significance. Proceedings of the National Academy of Science, 96: 3447-3454.

Provencio P.P. \& Polyak V.J., 2001 - Iron Oxide-Rock Filaments: Possible Fossil Bacteria in Lechuguilla Cave, New Mexico. Geomicrobiological Journal, 18 (3): 297.

Quesada S., Robles S. \& Rosales I., 2005 Depositional architecture and transgressiveregressive cycles within Liassic backstepping carbonates ramps in the Basque-Cantabrian Basin, $N$ Spain. Journal of the Geological Society, London, 162: 531-548.

Rossi C., Lozano, R.P., Isanta N. \& Hellstrom J., 2010 - Manganese stromatolites in caves: El Soplao (Cantabria). Geology, 38 (12): 11191122.

Spilde M.N., Northup, D.E. Boston P.J., Schelble R.T., Dano K.E., Crossey L.J., \& Dahm C.N., 2005 - Geomicrobiology of cave ferromanganese deposits: A field and laboratory investigation. Geomicrobiology Journal B, 22: 99-116.

Velasco F., Herrero M. \& Yusta I., 2003 - Geology and Geochemistry of the Reocin Zinc-Lead Deposit, Basque-Cantabrian Basin, Northern Spain. Economic Geology, 98 (7): 1371-1396.

White W.B., Vito C. \& Scheetz B.E., 2009 - The mineralogy and trace element chemistry of black manganese oxide deposits from caves. Journal of Cave and Karst Studies, 71 (2): 136-143. 